\title{
EFFECT OF HEMODIALYSIS ON OXIDATIVE STRESS IN PATIENTS WITH CHRONIC RENAL FAILURE
}

\section{KRONIKK RENAL YETMEZLIKLII HASTALARDA HEMODIYYALİZIN OKSİDATİF STRES ÜZERINDEKİ ETKİSI}

\author{
Aysun HACIŞEVKI \\ Gazi University, Faculty of Pharmacy, Department of Biochemistry, \\ 06330, Etiler-Ankara, TURKEY.
}

\begin{abstract}
Oxidative stress is at play in the progression of chronic renal failure (CRF) and in the genesis of atherosclerosis. The aim of the present study was to evaluate the factors that might influence the oxidativeantioxidative balance in patients on hemodialysis. The study group was consisted of 64 hemodialysis patients due to CRF. Twenty-two healthy subjects constituted a control group. We measured changes in serum superoxide dismutase and glutathione peroxidase activity, and malondialdehyde levels in chronic renal failure patients and compared with healthy control groups. Superoxide dismutase and glutathione peroxidase activity, and malondialdehyde levels were assayed with spectrophotometric methods. Superoxide dismutase activity of CRF patients group were higher than those of control group $(p<0.001)$. Glutathione peroxidase activity of CRF patients group were lower than those of control group $(p<0.001)$. Malondialdehyde levels in hemodialysis patients were higher than those of control group $(p<0.01)$. Several studies of SOD activity in chronic renal failure patients have found conflicting results. We propose that the increased SOD activity could be a protective mechanism for the cells due to the hyperproduction of free radicals in chronic renal failure. Decreased serum antioxidant activity in CRF patients on hemodialysis may contribute to the increased oxidative damage and in the development of renal complications. This study indicates the existence and increased production of oxidative stress resulting from hemodialysis and disturbance in antioxidant enzyme system. Our results supports that an increase in oxidative stress may be considered as one of the major risk factors in chronic renal failure patients.
\end{abstract}

Key words: SOD, GPx, Malondialdehyde, Chronic renal failure, Antioxidant enzymes 
ÖZET

Oksidatif stres kronik renal yetmezlik gelişiminde ve ateroskleroz gelişiminde rol oynamaktadir. Bu çalışmanın amacı hemodiyaliz hastalarında oksidatif-antioksidatif balansi etkileyebilen faktörleri değerlendirmektir. Çalışmaya 64 hemodiyaliz hastası, kontrol grubu olarak ise 22 sağllklı kişi dahil edilmişstir. Kronik renal yetmezlikli hastalarda serum süperoksit dismutaz, glutatyon peroksidaz aktiviteleri ve malondialdehid düzeylerindeki değişiklikler ölçüldü ve sağlıklı kontrol grubu ile karşılaştırıldı. Bu parametreler spektrofotometrik method kullanılarak tayin edildi. Hasta grubunun serum süperoksit dismutaz aktivitesi kontrol grubundan daha yüksek bulunmuştur ( $p<0.001$ ), glutatyon peroksidaz aktivitesi ise daha düşüktür $(p<0.001)$. Kronik renal yetmezlikli hastaların malondialdehid düzeyleri kontrol grubundan daha yüksektir $(p<0.01)$. Kronik renal yetmezlikli hastalarda süperoksit dismutaz aktivitesine yönelik çalı̧̧malarda çelişkili sonuçlar gözlenmektedir. Bu hastalarda artmışs süperoksit dismutaz aktivitesini, artmış serbest radikal üretimine bağll koruyucu bir mekanizma olarak değerlendirebiliriz. Çalışmamız, kronik renal yetmezlikli hastalarda majör risk faktörlerinden biri olarak düşünülen oksidatif stresteki artışl desteklemektedir.

Anahtar kelimeler: SOD, GPx, Malondialdehid, Kronik renal yetmezlik, Antioksidan enzimler

\section{INTRODUCTION}

Reactive oxygen species (ROS) play a key role in the pathophysiological pathways of a wide variety of clinical and experimental renal diseases (1-3). These ROS, including the superoxide anion, the hydroxyl radical, hypochlorous acid, and peroxynitrite may be generated by activated neutrophils, monocytes, and messangial cells during metabolic processes (4). ROS have been shown to be primary mediators in glomerulonephritis, and are factors in the regulation of glomerular permeability to proteins, development of morphologic lesions, and alteration of glomerular hemodynamics (ie, reductions of glomerular blood flow and glomerular filtration rate) (5).

Oxidative stress has been defined as a loss of balance between the production of free radical or reactive oxygen species and protective antioxidant systems. A profound imbalance between oxidants and antioxidants has been suggested in haemodialysis patients. In normal conditions, both systems are in a steady state in such a way that an increase in oxidative products is followed by a greater production by antioxidant systems. This balance always favors the antioxidant arm so that there is a safety zone $(6,7)$. 
There is increasing evidence about the presence of oxidative stress in chronic renal failure patients, and particularly in those submitted to hemodialysis therapy. This seems to be due to multiple factors including an increase in the production of agents from oxidative metabolism (oxygen- derived substances generated by activated leucocytes, transition metal compounds, and other toxins of different molecular weight), and a decrease in antioxidant defenses. Oxidative stress generated in a physiologic or pathologic way and harms the cellular constituents including membrane lipids, proteins, and DNA (6). Free radical-mediated changes are thought to be involved with atherosclerosis in patients with chronic renal failure. Oxidative damage due to reactive oxygen species has been reported to increase in uremic patients and has thus been suggested to be a possible factor contributing to the pathogenesis of atherosclerosis in chronic renal failure. There may be several potential sources of increased free radical production in chronic renal failure (8). The aim of the present study was to evaluate the factors that might influence the oxidativeantioxidative balance in patients on hemodialysis.

\section{MATERIALS AND METHODS}

CRF patients (34 females and 30 males) at Başkent University, Faculty of Medicine were enrolled in the study. The study group consisted of 64 hemodialysis patients due to chronic renal failure. The study was approved by the Başkent University Ethics Committee of Faculty of Medicine. The weekly duration of dialysis was $12 \mathrm{~h}$ in 3-4 h sessions. A control group consisted of 22 healthy persons, with no clinical symptoms of any disease and with the markers of renal function in the norm. All blood samples were collected from the ulnar vein, in the morning before a dialysis session. Following the collection of blood, serum was seperated immediately. Samples were centrifuged and the supernatant is removed and stored $-70{ }^{\circ} \mathrm{C}$ until the analysis.

We measured changes in superoxide dismutase and glutathione peroxidase activity, and malondialdehyde levels in chronic renal failure patients and compared with healthy control groups. The activities of both superoxide dismutase and glutathione peroxidase were determined with Cayman commercial kits. The levels of thiobarbituric acid reactive substances (TBARS) were also determined spectrophotometrically in terms of malondialdehyde (9).

All data are presented as means $\pm \mathrm{SE}$ and were statistically analyzed using a SPSS 10 for Windows. Mann Whitney $U$ test were applied to determine the significance of biochemical parameters among the groups. $\mathrm{P}$ value of $<0.05$ was considered as significant. 


\section{RESULTS AND DISCUSSION}

The general characteristics of hemodialysis (HD) patients and healthy subjects such as age, quetelet index, sex distribution are presented in Table 1.

Table 1. The demographic and clinical characteristics in HD patients and in controls.

\begin{tabular}{lcc} 
Parameters & Healthy subjects & HD Patients \\
\hline Number of patients & 22 & 64 \\
Sex (Male/Female) & $9 / 13$ & $30 / 34$ \\
Age (year) & $46.27 \pm 2.87$ & $47.28 \pm 1.68$ \\
BMI $\left(\mathrm{kg} / \mathrm{m}^{2}\right)$ & $23.97 \pm 0.61$ & $22.69 \pm 0.55$
\end{tabular}

Data are means \pm SE.

There are a great number of metabolic derangements in the course of CRF which become intensified in end-stage of renal disease, when dialysis is required (10). Impairments of enzymatic system have been reported such as glutathione peroxidase (GSH-Px) or superoxide dismutase (SOD), deficiency of selenium, zinc, copper, vitamins A, C, and E, and also diminished glutathione concentration in chronic renal failure (11). Oxidative stress is another accompaniment of CRF. Gerardi et al (10) and Marnett (12) have found increased serum concentrations of lipid peroxidation products malondialdehyde and 4-hydroxynonenal in hemodialysis patients. Mezzano et al (13) have revealed increased concentration of thiobarbituric acid reactive substances, which is a product of lipid peroxidation, and a higher level of advanced oxidation protein products in patients with uraemia. Nguyen-Khoa et al (14) have shown, in addition to high levels of thiobarbituric acid reactive substances and advanced oxidation protein products, a decreased activity of superoxide dismutase and glutathione peroxidase (11).

Biochemical parameters and the measured parameters are being presented in Table 2. Serum malondialdehyde levels, the biomarker of lipid peroxidation, were significantly increased in HD patients compared to healthy subjects $(\mathrm{p}<0.01)$ (Fig.1). 
Table 2. The demographic and clinical characteristics in serum of HD patients and controls.

Parameters

Healthy subjects

HD Patients

$(n=22)$

$(n=64)$

$\begin{array}{lll}\text { Superoxide dismutase }(\mathrm{U} / \mathrm{ml}) & 5.56 \pm 0.84 & 9.88 \pm 0.69^{+} \\ \text {Glutathione peroxidase }(\mathrm{nmol} / \mathrm{min} / \mathrm{ml}) & 121.85 \pm 5.82 & 56.69 \pm 1.85^{+} \\ \text {Malondialdehyde }(\mu \mathrm{mol} / \mathrm{L}) & 2.41 \pm 0.009 & 3.68 \pm 0.08^{*} \\ \text { Urea }(\mathrm{mg} / \mathrm{dL}) & 13.77 \pm 1.40 & 75.33 \pm 2.12^{*} \\ \text { Creatinine }(\mathrm{mg} / \mathrm{dL}) & 0.98 \pm 0.09 & 10.36 \pm 0.31^{*}\end{array}$

Data are means \pm SE.

${ }^{*}$ Significantly different from controls $(\mathrm{p}<0.01),{ }^{+}$Significantly different from controls $(\mathrm{p}<0.001)$

Oxidative stress is defined as an imbalance between oxidant production and antioxidant protection. Oxygen free radicals induce damage to tissue in many clinical conditions. Also, it is well known that, in the diseases in which excessive immunoinflammatory responses are present, formation of free radicals are accelerated $(6,7)$. Oxidative damage induced by reactive oxygen species (ROS) is thought to contribute to the development of macrophage foam cells in the walls of arteries, which may lead to lethal complications of chronic renal failure (CRF) patients such as cardiovascular disease $(15,16)$. CRF is a disease caused by damage to renal parenchyma by chronic pathologic processes leading to decreased glomerular filtration rate (GFR). Causes of CRF are multiple, with the predominance of primary glomerulonephritis $(26.4 \%)$, diabetic nephropathy (19.2\%), tubulointerstitial nephritis (16.5\%), hypertensive nephropathy (8.9\%), and polycystic kidney disease (8.9\%) (11).

There is increasing evidence about the presence of oxidative stress in chronic renal failure patients, and particularly in those submitted to hemodialysis therapy. This seems to be due to multiple factors including an increase in the production of agents from oxidative metabolism and a decrease in antioxidant defenses. Besides, the use of low biocompatible membranes and purity of dialysis water has an influence on oxidative stress $(6,17-19)$.

When free radicals overwhelm the antioxidant barrier, they become available for interacting with phospholipidic structures producing lipid peroxidation. One of the major components of this reaction is the production of malondialdehyde, which identification would allow us having an idea 
of the magnitude of lipid peroxidation. The results found in our patients are in agreement with those of many other authors regarding increased lipid peroxidation $(6,20-21)$.

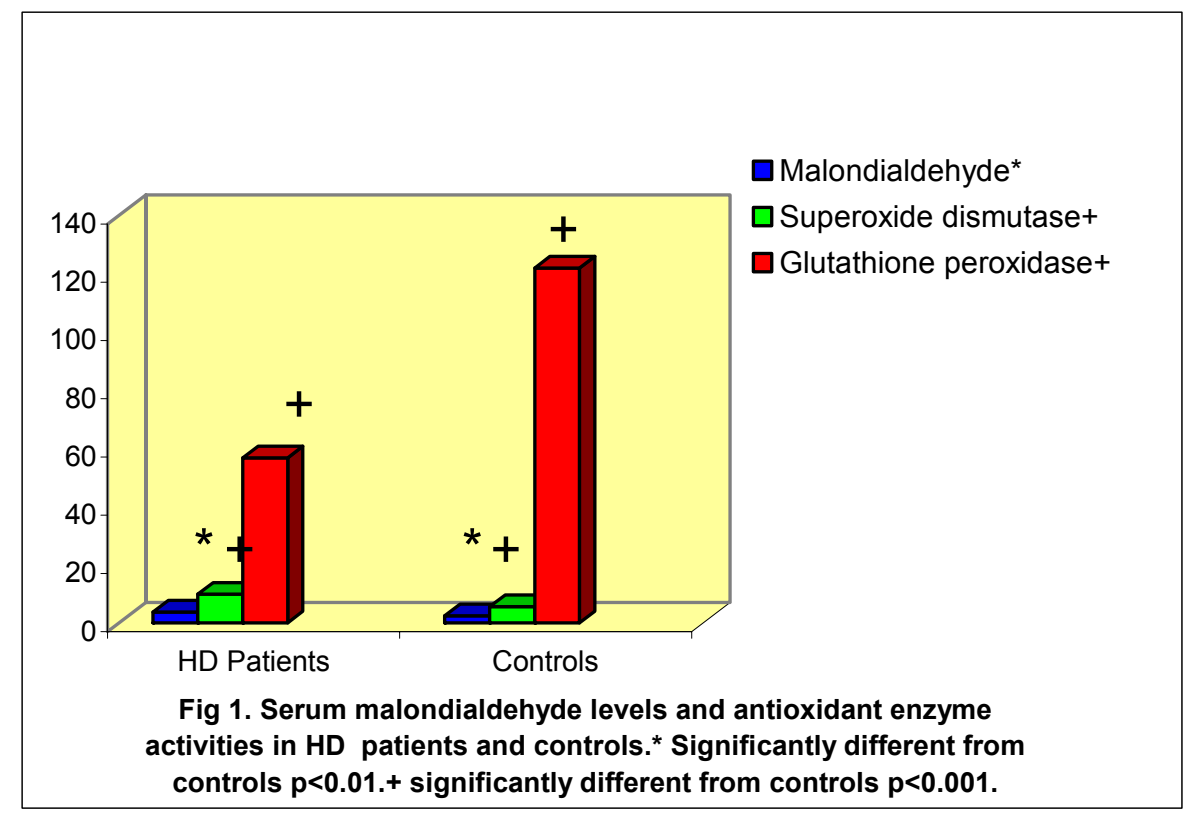

Serum superoxide dismutase levels were significantly increased in CRF patients compared to healthy subjects $(\mathrm{p}<0.001)$ (Fig.1). The plasma glutathione peroxidase levels of patient group have shown a significant decrease when compared with those of control group $(\mathrm{p}<0.001)$ (Fig.1). In addition, no relationship was found between measured parameters and clinical parameters in both cases and controls.

Several studies have shown decreased activity of glutathione peroxidase in patients with renal disorders and chronic renal failure (6-7,22-26). Glutathione peroxidase protects cells from oxidative damage by catalyzing the reduction of both organic and hydrogen peroxides, using glutathione as a reducing agent. GPx activity is an important test to assess the oxidative damage in patients with kidney diseases. Kidney proximal tubular cells are the main source of GPx activity in the plasma. The progression of renal disorders is accompanied by a decrease in GPx activity (22). Blood 'Se' levels are frequently reported to be lower in hemodialyzed patients (26). The integrity of GPX requires adequate intake of 'Se' (27) and its deficiency causes low activity of GPX and reduction in GPX-protein (apoenzyme) synthesis (28). During oxidative stress, inactivation of GPX may occur, and on the other hand superoxide anion itself can inhibit peroxidase function (29). The previous studies indicate an impairment of antioxidant systems and augmentation of oxidants during haemodialysis sessions (30-31). 
The superoxide dismutase enzyme is the front line of defense against reactive oxygen species-mediated injury (32). Several studies of SOD activity in chronic renal failure patients have found conflicting results (25-26,33-35). We propose that the increased SOD activities could be a protective mechanism for the cells due to the hyperproduction of free radicals in chronic renal failure. The increase in superoxide dismutase activity may originate from excess production of $\mathrm{O}_{2}{ }^{--}$ in macrophage. The lowering of plasma antioxidant activity in CRF patients on hemodialysis may contribute to the increased oxidative damage and in the development of renal complications. During haemodialysis, uraemic toxicity, malnutrition and the progressive worsening of clinical condition can lead to oxidative stress caused by an hyperproduction of oxidants including ROS and uraemic toxins with pro-oxidant function, and

defective antioxidant protection. Losses of antioxidants via dialysis and the use of low biocompatible membranes are the factors that may be responsible for the imbalance between oxidative and antioxidative mechanisms in HD patients. All these factors contribute to the higher oxidative stres in haemodialysis patients included in our study.

This study indicates the existence and increased production of an oxidizing stress resulting from hemodialysis and disturbance in antioxidant enzyme system. We found enhanced oxidative stress in all patient groups due to an increase in lipid peroxidation and reduced activities of glutathione peroxidase. Our results supports that an increase in oxidative stress may be considered to be as one of the major risk factors in chronic renal failure disease.

Acknowledgements: This study was supported by the Research Fund of Gazi University (02/2006-04).

\section{REFERENCES}

1. Baud, L.,Ardaillou, R., "Reactive oxygen species: production and role in the kidney" Am.J.Physiol., 251(5 Pt 2): F765-F776 (1986).

2. Nath, K.A., Salahudeen, A.K., "Induction of renal growth and injury in the intact rat kidney by dietary deficiency of antioxidants" J.Clin.Invest., 86(4): 1179-1192 (1990).

3. Yoshioka, T., Bills, T., Moore-Jarret, T., GBaud, L., reene, h.l., Burr, I.M., Ichikawa, I., "Role of intrinsic antioxidant enzymes in renal oxidant injury" Kidney Int., 38(2): 282$288(1990)$ 
4. Andreoli S.P., "Reactive oxygen molecules, oxidant injury and renal disease. Pediatr.Nephrol., 5(6):733-742 (1991).

5. Baud, L.,Ardaillou, R.,'Involvement of reactive oxygen species in kidney damage" Br.Med.Bull., 49(3): 621-629 (1993).

6. Gonzalez Rico, M., Puchades, M.J., Garcia Ramon, R., Saez, G., Tormos, M.C., Miguel, A., "Effect of hemodialysis therapy on oxidative stress in patients with chronic renal failure" Nefrologia, 26(2): 218-225 (2006).

7. Dursun, E., Dursun, B., Süleymanlar, G., Ozben, T., "Effect of haemodialysis on the oxidative stres and antioxidants in diabetes mellitus" Acta Diabetol., 42: 123-128 (2005).

8. Erdoğan, C., Ünlüçerçi, Y., Türkmen, A., Kuru, A., Çetin, Ö., Bekpınar, S., "The evaluation of oxidative stres in patients with chronic renal failure" Clin.Chim.Acta, 322: 157-161 (2002).

9. Slater,T.F., Sawyer, B.C.. "The stumulatory aeeact of carbon tetrachloride and other halogeno-alkanes on peroxidative reactions in rat liver fractions in vitro. General Features of the systems used", Biochem. J., 123: 805-814 (1971).

10. Gerardi, G., Usberti, M., Martini, G., "Plasma total antioxidant capacity in hemodialyzed patients and its relationships to other biomarkers of oxidative stres and lipid peroxidation", Clin.Chem.Lab.Med., 40: 104-110 (2002).

11. Mastalerz-Mıgas, A., Steciwko, A., Pokorski, M., Pırogowıcz, I., Drobnik, J., Bunio, A., Muszynska, A., Jasinska, A. "What influences the level of oxidative stres as measured by 8-hydroxy-2'-deoxyguanosine in patients on hemodialysis?", Journal of Physiology and Pharmacology, 57(Supp 4): 199-205 (2006).

12. Marnett, L.J., "Lipid peroxidation- DNA damage by malondialhyde”, Mutat. Re., 424: 8395 (1999).

13. Mezzano, D., Pais, E.O., Aranda, E., "Inflammation, not hyperhomocysteinemia, is related to oxidative stres and hemostatic and endothelial dysfunction in uremia, Kidney Int., 60: 18844-18850 (2001).

14. Nguyen-Khoa, T., Massy, Z.A., De Bandt, J.P., “ Oxidative stres and hemodialysis: Role of inflammation and duration of dialysis treatment", Nephrol.Dial.Transplant., 16: 335-340 (2001). 
15. Danielski, M., Ikizler, T.A., McMonagle, E., "Linkage of hypoalbuminemia, inflammation and oxidative stres in patients receiving maintenance hemodialysis therapy" Am.J.Kidney Dis., 42:286-294 (2003).

16. Kaysen, G.A., "Inflammation and oxidative stres in end-stage renal disease" Adv.Nephrol., 30:201-214 (2000).

17. Morena, M., Cristol, J.P., Canaud, B., "Why hemodialysis patients are in a prooxidant state? What could be done to correct the pro/antioxidant imbalance", Blood Purif., 18(3): 191-199 (2000).

18. Pawlak, K., Pawlak, D., Mysliwiec M., "Cu/Zn superoxide dismutase plasma levels as a new useful clinical biomarker of oxidative stress in patients with end-stage renal disease", Clin. Chem., 38: 700-705 (2005).

19. Canaud, B., Cristol, J., Morena, M., Leray-Moragues, H., Bosc, J., Vaussenat, F., "Imbalance of oxidants and antioxidants in haemodialysis patients" Blood Purif., 17(2-3):99106 (1999).

20. Martin-Mateo, M., Sanchez-Portugal, M., Iglesias, S., De Paula, A., Bustamante, J., “Oxidative stres in chronic renal failure” Renal Fail., 21:155-167 (1999).

21. Fiorillo, C., Olivier, C., Rizzuti, G., Nediani, C., Pacini, A., Nassi, P., "Oxidative stres and antioxidants defenses in renal patients receiving regular haemodialysis" Clin.Chem.Lab.Med., 36(3):149-153 (1998).

22. El-Far, M.A., Bakr, M.A., Farahat, S.E., Abd El-Fattah, E.A., "Glutathione peroxidase activity in patients with renal disorders" Clin.Exp.Nephrol., 9(2):127-131 (2005).

23. Nouri, M., Rahbam-Nobar, M., Argani, H., Rokhforooz, F., "Superoxide dismutase and glutathione peroxidase in hemodialyzed patients and renal transplant recipients and their relationship to osmotic fragility" Medical J.Islamic Acad.Sci.,12(2):33-38 (1999).

24. Büyükbaş, S., İnal, A., Atalay, H., "Hemodiyaliz hastalarında oksidatif aktivitenin değerlendirilmesi” Tıp Araştırmaları Dergisi, 5(3):105-110 (2007).

25. Paul, J.L., Sall, N.D., Soni, T., Poignet, J.L., Lindenbaum, A., Man, N.K., Moatti, N., Raichvarg, D., "Lipid peroxidation abnormalities in hemodialyzed patients" Nephron, 64(1):106-109 (1993). 
26. Richard, M., Arnaud, J., Jurkovitz, C., "Trace elements and lipid peroxidation abnormalities in patients with chronic renal failure" Nephron, 57:10-15 (1991).

27. Hussein O, Rosenblat M, Refael G and Avtram M "Dietary Selenium increases cellular Glutathione perocidase activity and reduces the enhanced susceptibility to lipid peroxidation of plasma and low density lipoprotein in kidney transplant recipients" Transplantation, 63(5):679-685 (1997).

28. Takahashi K, Newburger PE and Cohen $\mathbf{H J}$ "Glutathione peroxidase protein absence in selenium deficiency states and correlation with enzymatic activity” J Clin Invest, 77:14021404 (1986).

29. Blum J and Fridovich I "Inactivation of glutathione peroxidase by superoxide radical" Arch Biochem Biophys, 240:500-508 (1985).

30. Morena, M., Cristol, J.P., Bosc, J.Y., "Convective and diffusive losses of vitamin C during haemodiafiltration session: a contributive factor to oxidative stress in haemodialysis patients" Nephrol.Dial.Transplant., 17:422-427 (2002).

31. Mayer, B., Zitta, S., Greilberger, J., "Effect of hemodialysis on the antioxidative properties of serum" Biochim.Biophys.Acta, 1638:267-272 (2003).

32. Mates, J.M., Perez-Gomez, C., Nunez de Castro, I., "Antioxidant enzymes and human diseases", Clin.Biochem., 32: 595-603 (1999).

33. Toborek, M., Wasik, T., Drozdz, M., Klin, M., Manger-Wrobel, K., KopiecznaGrzebieniak, E., "Effect of hemodialysis on lipid peroxidation and antioxidant system in patients with chronic renal failure", Metabolism, 41: 1229-1232 (1992).

34. Stenvinkel, P., Holmberg, I., Heimburger, O., Diczfalusy, U., "A study of plasmalogen as an index of oxidative stress in patients with chronic renal failure. Evidence of increased oxidative stress in malnourished patients", Nephrol.Dial.Transplant., 13:2594-2600 (1998).

35. Mimic-Oka, J., Simic, T., Djukanoviç, L., Reljic, Z., Davicevic, Z., “Alteration in plasma antioxidant capacity in various degrees of chronic renal failure", Clin.Nephrol., 51: 233-241 (1999). 